\title{
Registerbasert epidemiologisk forskning og forvaltning - et resultat av tilfeldighetenes spill eller en uunngåelig historisk utvikling?
}

\author{
Lorentz M. Irgens ${ }^{1,2}$ \\ 1) Medisinsk fødselsregister, Locus for registerepidemiologi, Det medisinske fakultet, Universitetet i Bergen og \\ Nasjonalt folkehelseinstitutt \\ 2) Institutt for samfunnsmedisinske fag, Universitetet i Bergen \\ Korrespondanse: Lorentz M. Irgens, Medisinsk fødselsregister, Kalfarveien 31, 5018 Bergen, e-post: lorentz.irgens@mfr.uib.no
}

\section{BAKGRUNN}

Et festskrift har vanligvis en begrunnelse og utgis fortrinnsvis $\mathrm{i}$ en festlig anledning. Nærværende festskrift synes å kunne tilskrives minst tre ulike anledninger:

- først og fremst feires Medisinsk fødselselregisters 40-årsjubileum

- dernest markeres at undertegnede har ledet registeret i 25 år

- og at jeg samtidig går av som leder for Medisinsk fødselsregister

Leseren vil nok være enig i at disse anledningene ikke alle er like betydningsfulle og, vil jeg hevde selv, like festlige (den sistnevnte). I tillegg er minst to av dem diskutable (de to førstnevnte), men mer om dette senere. Redaktørene har bedt meg om et mer personlig innlegg til festskriftet, noe jeg etterkommer i det følgende.

\section{INNLEDNING}

Gjennom årene får man mange henvendelser og oppdrag. Hvis man ikke er flink til å si nei kan det nok bli en del opptredener med forelesninger og foredrag av ulik art og av ulik betydning. Men for en tid siden fikk jeg en henvendelse litt utenom det vanlige som fikk meg til å gjøre noen refleksjoner. Jeg ble spurt om å holde kullets tale ved avslutningen for de unge legene som skulle ut i turnustjeneste.

I første omgang følte jeg henvendelsen som meget smigrende. Forebyggende medisin og epidemiologi er vel neppe kjent for å representere de mest populære fagene i medisinerstudiet. Blant mine budskap til studentene er alltid følgende: i studietiden blir det krevet av dere at dere skal bli fortrolige med den kliniske arbeidsmåten. Dere blir stilt overfor den enkelte pasient og må bli i stand til å stille en korrekt diagnose og gi en effektiv behandling. Dette krever ikke bare en betydelig intellektuell mobilisering, men også en emosjonell deltakelse med medfølelse og personlig engasjement. Men vit at i tillegg til dette krever medisinfaget mer av dere hvis det skal bli til gagn for deres neste; hvis faget skal bli et gode for befolkningen. Dere må forstå at fagets ansvar ikke er avgrenset til den enkelte pasient, men angår hele befolkningen.
Et slikt utsagn blir lett til tomme talemåter for en ung lege som ønsker å komme ut som kirurg så snart som mulig for å redde sin kritisk syke pasient. Derfor må det innrømmes at forebyggende medisin og epidemiologi har hatt problemer med å komme på medisinerstudentenes popularitetstopp. Så meget desto mer ble jeg smigret av studentenes henvendelse, i den grad den kunne sees som uttrykk for popularitet.

Etter de innledende refleksjoners søte kløe kom snart den sure svie: hva skulle jeg gi til beste ved denne spesielle anledningen? Det var egentlig ganske nærliggende å ta utgangspunkt i de valg man står overfor ved starten av karrieren, da så meget bestemmes for resten av livet. Mitt innledende spørsmål var: hvor meget bestemmer vi selv gjennom målrettet planlegging og hvor meget skjer på grunn av tilfeldigheter? (Noen hevder at tilfeldigheter knapt eksisterer og at vi er utsatt for skjebnens spill med oss, men dette gikk jeg ikke nærmere inn på).

Selv som epidemiolog (med større tro på årsakssammenhenger enn på at alt er resultater av tilfeldighetsprosesser) var min tese at det aller meste som skjer oss (i hvert fall i slike sammenhenger) skyldes tilfeldigheter, men at våre reaksjoner på disse tilfeldighetene kan være nokså avgjørende; i hvilken grad vi evner å utnytte dem; en variant av romernes "carpe diem". Dette prøvet jeg å illustrere og underbygge ved eksempler fra eget liv. Og her er vi kanskje ved et mulig poeng ved denne innledende diskursen: er registerepidemiologien oppstått nærmest ved en tilfeldighet eller er den vokset frem som en historisk nødvendighet?

\section{LEPRAREGISTERET}

Mitt eget forhold til registerepidemiologi oppstod ved en ren tilfeldighet. I 1970 var jeg ferdig med militærtjenesten og skulle finne meg et levebrød. To premisser ble lagt til grunn, hvorav det ene var relativt trivielt for de fleste; som bergenser ønsket jeg å leve et liv preget av en lykkelig og forløst kjærlighet til min fødeby. Dernest ønsket jeg å arbeide med en del av medisinen som kunne være en utfordring til tanken. Uten å gå nærmere inn på hvilke medisinske aktiviteter som derved ble utelukket, endte det med at jeg fikk et vikariat som assistentlege ved Patologisk anatomisk 
avdeling, Gades institutt; jeg var opptatt av fagets patofysiologiske utfordringer, ikke de morfologiske aspekter (og hadde sikkert blitt en dårlig diagnostiker).

Etter et par uker kom min sjef, professor Erik Waaler, innom på kontoret: "Irgens har jo interesser innenfor medisinsk historie. Om han kunne finne frem noe til Den 10. internasjonale leprakongressen". (Man var ikke dus med sine underordnede på den tiden og tiltalen var i 3. person.) Kongressen skulle arrangeres $i$ 1973 i Bergen, 100 år etter Armauer Hansens oppdagelse av leprabasillen. Problemstillingen var å avklare årsaken til at Armauer Hansen mente at sykdommen var smittsom. Plikttro som jeg er, førte denne anmodningen til at materialer som fantes i St. Jørgens Hospital og Pleiestiftelsen for spedalske no. 1 måtte gjennomletes. Waaler og professor Thomas M. Vogelsang, som hadde arbeidet mye med lepraens historie i Norge, hadde særlig tro på amtlegenes årsberetninger.

A bli stilt overfor levninger av gamle dokumenter på loftsgulv dekket av løv og spindelvev var en ganske frustrerende og overveldende utfordring. Etter et par måneders ryddeinnsats med blindspor i form av bygdebøker og de nevnte amtslegers årsberetninger, gikk det gradvis opp for meg at de gamle haugene av dokumenter inneholdt et landsomfattende pasientregister for lepra. Registeret viste seg å være blitt opprettet i 1856 ved kgl. resolusjon, og hadde komplette opplysninger om pasientene over en hundreårsperiode [1]. Materialet inneholdt bl.a. meldeskjemaene og notatene i de sentrale registerprotokollene. En egen protokoll inneholdt et komplett sykehusregister for leprasykehusene i den samme perioden.

Dermed ble min karriere som patolog avsluttet. Jeg meldte meg for professor Tor Bjerkedal, sjef for det daværende Institutt for hygiene og sosial medisin, Universitetet i Bergen. Han var da i ferd med å etablere Medisinsk fødselsregister i Bergen på oppdrag fra Helsedirektør Karl Evang. Bjerkedal hadde ingen problemer med å forstå betydningen av den datasamlingen jeg hadde med meg. Den kunne gi grunnlag for en bred analyse av sykdommens epidemiologi. Waaler hadde allerede skaffet meg et stipend fra Forskningsrådet. Han hadde kanskje raskt avskrevet meg som et stort patologisk talent; i hvert fall samtykket han generøst og uten innvendinger til at jeg umiddelbart fikk mitt arbeidssted hos Bjerkedal.

Både Bjerkedal og jeg var overbevist om at løsningen på lepraens gåte (en talemåte som jeg senere skulle stifte bekjentskap med i forbindelse med krybbedødsepidemien på 1980-tallet) ikke lå i tilfeldige observasjoner som kunne finnes i bygdebøker eller amtlegenes årsberetninger, men i longitudinelle opplysninger for hver enkelt pasient samlet inn på en standardisert måte, systematisk for alle pasienter i landet, over 100 år. Samlet utgjorde disse opplysningene verdenshistoriens første nasjonale pasientregister; samtidens imponerende satsing mot et meget alvorlig helseproblem [1].
Interessant nok var denne samlingen av pasientdata aldri blitt oppfattet eller omtalt som noe register, hverken av samtiden eller ettertiden. Oppdagelsen av registeret må derfor karakteriseres som et typisk tilfeldig funn. Imidlertid, våre intensjoner om å kaste nytt lys over sykdommens epidemiologi ved hjelp av registeret var langt fra nye. Allerede i 1858 uttalte den første Overlege for den spedalske sykdom, Ove Guldberg Høegh, at det var ved hjelp av disse pasientopplysningene at man skulle lære å kjenne årsaken til sykdommen [2]. Og slik ble det; bearbeidelse av Lepraregisteret ga kunnskap som sterkt underbygget at lepra var en smittsom sykdom, kunnskap som var sentral i Armauer Hansens argumentasjon da han i 1873 oppdaget leprabasillen [3].

Forøvrig er det vel riktig å si at Lepraregisteret i sin tid ble underutnyttet og særlig sett i lys av Høeghs visjoner. Registeret ble først og fremst benyttet til helseovervåking og som ledd i oppfølging av pasientene. I langt mindre grad kom det til anvendelse i epidemiologiske analyser. På mange måter var Lepraregisteret forut for sin tid; de informasjonsteknologiske forutsetningene for en mer omfattende utnyttelse manglet.

Bearbeidelsen av Lepraregisteret mer enn 100 år senere ble mitt doktorarbeid. Prosessen ble meget tidkrevende, selv med bruk av "moderne" informasjonsteknologi i form av hullkort og punchemaskiner. Det viste seg at det var registrert totalt 8231 pasienter fra 1856 til 1950, mange med tallrike meldinger til registeret. Blant resultatene [4] kan nevnes de viktigste årsakene til at sykdommen til slutt ble utryddet i Norge:

- isolasjon av smittefarlige pasienter i form av hospitalisering

- emigrasjon av høyrisikogrupper til USA

- (menn omkring 20 år i Sogn og Fjordane fylke hadde den høyeste emigrasjonsprosenten og den høyeste insidensen)

- forbedring av ernæringssituasjonen i høyinsidensområdene, spesielt med hensyn på protein.

Videre viste sykdommen utpregede kohortfenomener. De fleste pasientene ble smittet i tidlig barndom og alder ved debut ble bestemt av inkubasjonstidens lengde. Et karakteristisk trekk ved fallende insidens var økende debutalder. Dette påviste vi senere også i andre land der det forelå pasientdata [5]. Fenomenet skyldes at mot slutten av en epidemi blir det relativt flere pasienter med lang inkubasjonstid og disse har nødvendigvis en relativt høyere debutalder. Det er grunn til å tro at fenomenet gjør seg gjeldende ved enhver sykdom der en relativt stor andel av de syke har en lang latenstid mellom eksponering og debut.

Arbeidet med Lepraregisteret førte senere til forskning knyttet til leprabasillens evne til å overleve utenfor den menneskelige organisme. Denne forskningen var i stor grad et resultat av tilfeldigheter, men har ikke direkte tilknytning til registerepidemiologi (se f.eks. [6]), og vil derfor ikke bli nærmere omtalt her. 
Merkelig nok var det ikke vanskelig å få publisert arbeidene basert på Lepraregisteret. Genren var unektelig noe ukurant; historikerne ville kanskje kunne hevde at man ikke hadde benyttet vanlig historisk metode, mens epidemiologene ville kunne fremholde at det her var tale om forhold som ikke var særlig dagsaktuelle. (Dette er i realiteten et problem ved all epidemiologisk forskning av tilstander med lange latenstider, men vanligvis ikke i den grad det her er tale om). Leprakongressen i Bergen i 1973 bidro nok til at interessen for Lepraregisteret ble vekket og ga publiseringen av resultatene en god start. At Verdens helseorganisasjon (WHO), i mangel av tilsvarende datagrunnlag fra andre land, fattet interesse for det norske registeret bidro også sterkt. WHO mente at epidemiologisk lepraforskning og folkehelsearbeid i større grad burde bygge på pasientregistre og anmodet min førsteopponent, Michel Lechat ved Louvain-universitetet i Brüssel og meg om å bidra til etablering av et lepraregister i Portugal. Registeret ble basert på gamle pasientjournaler og dekket en periode fra ca. 1946 til 1980. Analysene viste klare likhetstrekk med funnene fra Norge [7].

Denne interessen har også vedvart i senere år. En gruppe i Rotterdam fikk for endel år siden støtte fra WHO til å utarbeide epidemiologiske prediksjonsmodeller for lepra under forutsetning av at modellene skulle utprøves på det norske lepraregister [8]. Dette førte til at vår opprinnelige bearbeidelse av registeret ble gått meget nøye etter i sømmene. Til min glede ble det ikke påvist feil; noe som lett kan oppstå ved bearbeidelsen av kompliserte datastrukturer. En annen glede var det at UNESCO i 2001 satt Lepraregisteret $i$ Bergen på sin liste: Memory of the World som første bidrag fra Norge. Å få etablert en lokal forvaltning av denne verdensarven $\mathrm{i}$ form av De medisinsk historiske samlinger i Bergen, herunder Lepramuseet, som i 2006 ble integrert $\mathrm{i}$ Bergen bymuseum og den livskraftige venneforeningen Medisinsk historisk selskap, har også vært en tilfredsstillelse.

Allerede på 1970-tallet var det samlet mange dyktige fagfolk i miljøet på Institutt for hygiene og sosialmedisin samt Det medisinske fakultets EDB-seksjon. EDB-seksjonen var, med Bjerkedal som styreformann, i personalunion med instituttet. Mange av disse fikk stor betydning for arbeidet med Lepraregisteret. Spesielt vil jeg nevne Anne-Grethe Sleire Graham, som var sentral $i$ et komplisert og omfattende punchearbeid, og statistikeren Rolv Skjærven, som deltok særlig i de senere analysene av Lepraregisteret der også komparative aspekter $\mathrm{i}$ forhold til andre land ble studert [5]. Begge, og tallrike andre, har jeg hatt et meget godt samarbeid med $\mathrm{i}$ andre sammenhenger, for manges vedkommende helt frem til i dag.

\section{MEDISINSK FØDSELSREGISTER}

I 1970 kom jeg inn i et sterkt epidemiologisk miljø der betydelige analytiske og tekniske ressurser var rettet mot én overordnet oppgave: å opprette og drive Medisinsk fødselsregister (MFR). Med seg hadde Bjerkedal unge entusiaster som Leiv S. Bakketeig og Egil Henrik Lehmann.

\section{De forste årene}

Medisinsk registrering av fødsel var innført per 1/11967 på initiativ fra Helsedirektoratet, og utnyttelsen av de registrerte data ble overlatt Statistisk sentralbyrå. De første årgangene ble prosessert av SSB der bl.a. Gro Harlem Brundtland deltok i arbeidet. Noe register per se ble imidlertid ikke opprettet, og det ble snart enighet om at den videre bearbeidelse og utnyttelse av opplysningene ikke var en naturlig oppgave for SSB. Derfor kunne Tor Bjerkedal, som hadde vært medisinsk konsulent i SSB, ta med seg de første årgangene av MFR til sitt professorat i Bergen og opprette MFR som register ved UiB. MFR har således fullstendige årganger fra og med 1967, men selve registeret ble som institusjon først etablert i 1970. Tidligere MFRjubiléer har likevel blitt feiret med utgangspunkt i 1967; så også 40-årsjubiléet i år.

I motsetning til Lepraregisteret kom opplysningene i MFR raskt til anvendelse. Bjerkedal og medarbeidere benyttet allerede de første årgangene som grunnlag for analyser, for eksempel av fødselsutfall hos antatte høyrisikogrupper som kvinner med epilepsi [9], tuberkulose [10] og astma [11]. Bakketeig benyttet registerdata for å belyse gjentakelsesrisikoen for lav fødselsvekt og for tidlig fødsel [12]. Det ble også etablert et system for epidemiologisk overvåking av medfødte misdannelser og andre uønskede svangerskapsutfall for å avdekke eventuelle hyppighetsøkninger så tidlig som mulig [13]. Et viktig formål med å opprette registeret ble dermed ivaretatt; å forebygge en ny katastrofe lik den legemiddelet thalidomide forårsaket på slutten av 1950-tallet. Dette legemiddelet ble benyttet av gravide mot kvalme og søvnløshet fordi det ble ansett som ufarlig i svangerskapet. Totalt fikk mer enn 10.000 barn alvorlige medfødte misdannelser før denne bivirkningen ble oppdaget.

\section{Organisatorisk tilknytning}

I 1976 forlot Bjerkedal sitt professorat i Bergen etter å ha blitt utnevnt $i$ tilsvarende stilling ved Universitetet $i$ Oslo. MFR var Bjerkedals hjertebarn, og han hadde et ønske om å bringe registeret med seg til Oslo. Men dette viste seg å være komplisert. Byråkrati tar ofte tid. I tillegg var det ved UiB etter hvert vokset frem en forståelse for hvilken unik ressurs registeret representerte, en forståelse som hadde slått rot hos universitetets sentrale ledelse så vel som i Det medisinske fakultet.

Organisatoriske aspekter ved MFR var imidlertid satt på dagsordenen lenge før Bjerkedal flyttet til Oslo. Allerede i 1972 tok Helsedirektøren opp et forslag om et nærmere samarbeid mellom bl.a. Statens institutt for folkehelse, Kreftregisteret og MFR innen databehandling og administrasjon. Sosialministeren fremmet et 
slikt forslag uten at noen samordning ble iverksatt. Et nytt initiativ ble tatt i 1975 og i 1979 forelå "Utredningen om samarbeid mellom de sentrale epidemiologiske institusjoner (USEI)".

Parallelt med dette nedsatte Helsedirektoratet en arbeidsgruppe for å utrede den fremtidige organisering og plassering av MFR. Det ble foreslått at MFR skulle inngå i Statens institutt for folkehelse som en avdeling og at det kunne ligge i Bergen til tjenlige arbeidsforhold måtte foreligge i Oslo. Ingen av disse initiativene medførte endringer, og et nytt utvalg foreslo i 1978 at MFR burde lokaliseres til Oslo og legges under Statens institutt for folkehelse. Heller ikke denne anbefalingen ble fulgt, dels fordi UiB i 1979 ba om enda en utredning om MFRs fremtidige organisasjon og drift.

En ny arbeidsgruppe (Hareide I-utvalget) anbefalte at MFR skulle knyttes til Statens institutt for folkehelse med en seksjon i Oslo og en i Bergen. Utredningen medførte imidlertid ingen endringer for MFR og en ny arbeidsgruppe (Hareide II) kom i 1983 med anbefalinger som dannet grunnlaget for en avtale mellom Statens institutt for folkehelse og UiB om MFR. Her ble "sentrale funksjoner i forbindelse med å tilrettelegge de data som innsamles til MFR ... gitt som et langsiktig oppdrag til UiB”. I 1984 fastsatte så Helsedirektøren "Statutter for Medisinsk fødselsegister" med Helsedirektoratet som registereeier og Statens institutt for folkehelse som driftsansvarlig.

Alle disse utredningene tok tid, og i mellomtiden skulle registeret også ha en ledelse. Etter Bjerkedals avgang i 1976 fungerte jeg som leder av instituttet så vel som EDB-seksjonen. Samtidig ble instituttleder av UiB pålagt det formelle arbeidsgiveransvar, slik at jeg fra dette tidspunktet fikk et visst lederansvar for MFR i det interregnum som oppsto. I praksis avviklet Bjerkedal sin ledelse av MFR over en lengre periode som var preget av et godt samarbeid.

Fra 1982 hadde jeg i praksis overtatt ledelsen av MFR [14] og deltok således i begge Hareideutvalgene. Ledelsen ble i 1984 kombinert med et professorat II i hygiene ved UiB, forøvrig det siste $\mathrm{i}$ Norge (nå kalles faget forebyggende medisin). I 1986 ble jeg formelt ansatt som overlege og leder av MFR. Fra 1991 ble denne stillingskombinasjonen snudd slik at hovedstillingen ble professoratet $\mathrm{i}$ forebyggende medisin med ledelsen av MFR i bistilling, en ordning som fortsatte frem til 2002. På denne måten bidro UiB til driften av MFR og likeledes med tilsvarende ordninger for Rolv Skjærven, Rolv Terje Lie, Stein Emil Vollset, Anne Kjersti Daltveit, Kari Klungsøyr, Svein Rasmussen og Nina Øyen. Dermed ble tung vitenskapelig kompetanse knyttet til MFR.

I 2002 ble MFR integrert som en avdeling i det nye Nasjonalt folkehelseinstitutt (FHI) der jeg fortsatte som leder av MFR, nå som avdelingsdirektør og fremdeles kombinert med professoratet $\mathrm{i}$ forebyggende medisin. Samtidig ble det inngått en avtale om fortsatt samarbeid om MFR mellom FHI og UiB som bidrar med ytterligere 3 vitenskapelige stillinger til vitenska- pelig utnyttelse av registermaterialet.

Integreringen av MFR i FHI bidro til å løse et problem som var blitt stadig mer følbart; den lange avstanden, organisatorisk sett, til de sentrale helsemyndigheter. I 2002 ble MFR en del av landets helsevesen, noe som innebar en understrekning av MFRs forvaltningsmessige betydning og verdi. Konkret kan MFRs forvaltningsansvar eksempelvis illustreres ved utviklingen av kvalitetsindikatorer for fødselshjelpen, som foreligger i 2007.

\section{Forvaltningsmessige utfordringer}

Det opprinnelige meldeskjemaet ble beholdt til 1998 . Dermed fikk 30 årganger en standardisert registrering, noe som innebar en stor analytisk fordel. Men etter hvert ble det klart at en revisjon var nødvendig. MFR tok initiativ overfor Helsedirektoratet allerede i 1990. Arbeidet skulle vise seg å bli en langvarig utfordring. Det nye skjemaet inneholder endel nye opplysninger; om kosttilskudd og, med samtykke, om mors røkevaner og yrke. For øvrig avviker det fra det gamle først og fremst ved at fritekst $\mathrm{i}$ stor utstrekning er erstattet av avkrysningsmuligheter. $\AA$ få aksept for nødvendigheten av opplysninger om mors røkevaner ble meget vanskelig og tidkrevende. Fremdeles er det et problem at denne opplysningen og yrkesopplysninger, i motsetning til de øvrige, er avhengig av samtykke; en bestemmelse som ble innført etter forslag fra Datatilsynet. Det er et problem at en økende andel, nå henimot 20\% ikke ønsker å oppgi sine røkevaner.

Den rivende utviklingen innenfor informasjonsteknologien, med nye registreringsmetoder og stadig større regnekapasitet, ble utnyttet internt ved MFR uten alvorlige komplikasjoner. Annerledes ble det på 1990-tallet da det viste seg at fødeavdelingene etterhvert tok i bruk IT-systemer for utfylling av meldeskjemaene. Systemene ble innfort uten at MFR ble informert og uten MFRs godkjennelse. Etterhvert forelå systemene i mange utgaver og mange av dem viste seg å være beheftet med alvorlige feil og tilsvarende konsekvenser for MFRs datakvalitet. Disse feilene oppsto spesielt etter at MFR i 1999 hadde tatt i bruk det nye meldeskjemaet. En omfattende redegjørelse finnes i årsmeldingen for 1999-2000 [15].

I jubileumsåret er MFR involvert $i$ en ny omlegging av melderutinene ved at meldingene skal sendes elektronisk fra fødeavdelingene til MFR; en omlegging der MFR er pionér også i internasjonal sammenheng. Det er imidlertid et problem at 3-4 systemleverandører har delt markedet mellom seg i en konkurransesituasjon. Det betyr at MFR må vurdere og godkjenne et tilsvarende antall systemer. Ved MFR håper vi at en vel fungerende elektronisk melding vil frigi arbeidskraft, hittil benyttet til registrering, til kvalitetssikrende arbeidsoppgaver.

Omleggingen til elektroniske meldinger omfatter også registreringen av nemndbehandlede svangerskapsavbrudd, som fra 1999 er lagt til MFR. Dette ble gjort fordi antall avbrudd som følge av prenatal diag- 
nostikk (§ 2c i abortloven) økte på 1990-tallet. Ikke alle disse ble meldt til MFR og dermed ble grunnlaget for overvåking av medfødte misdannelser svekket. Fra 2007 er også registreringen av selvvalgte avbrudd lagt til MFR.

Utover på 1990-tallet ekspanderte MFR i betydelig grad. Fra en start med ca. 6-8 medarbeidere har MFR i jubileumsåret 60 ansatte inklusive stipendiater. Ekspansjonen gjorde det nødvendig med en mer formell organisering av arbeidet slik at det etter hvert er opprettet seksjoner for mottak av data, IT, oppdrag, Den norske mor og barn undersøkelsen, abortregistreringen, Biobankregisteret og administrasjon. I jubileumsåret ledes seksjonene av Kari Klungsøyr, Erik LieNielsen, Pat Schreuder, Kristin Gåsemyr, Nina Hovland og Nina Reigstad.

Ekspansjonen medførte alvorlige plassproblemer i Armauer Hansens hus (MFH-bygget) og planarbeider, som strakte seg over en årrekke, førte ikke frem. I 2002 ble vi tilfeldigvis oppmerksom på at Entra eiendom ønsket nye leietakere i Pleiestiftelsen for spedalske no 1 . I godt og nært samarbeid mellom UiB og FHI ble det lagt grunnlag for at MFR i 2003 kunne flytte inn i meget egnete lokaler, åpnet av helseminister Dagfinn Høybråten og med hilsningstale av Gro Harlem Brundtland. Her ble MFR samlokalisert med Institutt for samfunnsmedisinske fag. Ved nok en tilfeldighet ble en registerepidemiologisk sirkel sluttet.

\section{Juridisk grunnlag}

Medisinsk melding av fødsel ble etablert i 1967 i medhold av jordmorloven av 1898 og lov om legers rettigheter og plikter av 1927 . Videre bygget melderutinen på to rundskriv i 1966 fra Helsedirektoratet, henholdsvis til landets fylkesmenn og offentlige leger. Endelig fikk MFR sine statutter av Helsedirektoratet i 1984. Da Datatilsynet ble opprettet i 1980, fikk MFR konsesjon. For enkelte jurister med interesse for medisinske registre var imidlertid ikke dette hjemmelsgrunnlaget tilstrekkelig, og vi gikk på 1990-tallet inn i en periode der MFRs juridiske grunnlag ble trukket $\mathrm{i}$ tvil. Dette ble en periode med kamp på mange fronter. I tillegg til de juridiske problemene måtte vi slite for å skaffe det økonomiske grunnlaget for driften. Vi møtte stor forståelse ved UiB som bidro vesentlig. Forøvrig ble driftsgrunnlaget $\mathrm{i}$ stor grad etablert gjennom dekningsbidrag knyttet til prosjektmidler. Den tredje fronten var den faglige kampen for å få gjennomslag for registerepidemiologisk forskning (mer om dette senere).

Lov om helseregistre som ble vedtatt i 2001, betydde en enorm lettelse. Loven ga hjemmel for Forskrift for MFR, som kom allerede samme år. Dermed fikk MFR et uangripelig juridisk grunnlag samtidig som vi fikk et dokument til stor hjelp i den daglige driften. Helse- og omsorgsdepartementet planlegger for tiden en revisjon av forskriften for å gjøre den enda mer tjenlig for MFRs formål.

\section{Faglig gjennomslag}

Før Tor Bjerkedal flyttet til Oslo og i de første årene deretter hadde jeg liten direkte faglig tilknytning til MFR. Bearbeidelsen av Lepraregisteret tok mye tid og som skolelege i bistilling var jeg også sterkt opptatt av å bidra til å orientere skolehelsetjenesten mot stadig mer påtrengende utfordringer $\mathrm{i}$ form av psykososiale helseproblemer (se f.eks. [16]). Jeg ønsket heller ikke å "trakke på annen manns grunn". Nok en tilfeldighet inntraff i 1980 da Institutt for hygiene og sosialmedisin fikk besøk av professor Donald R. Peterson som gjesteprofessor fra University of Washington, Seattle. Peterson hadde et internasjonalt kjent navn innenfor krybbedødsforskning og holdt seminarer ved instituttet om denne gåtefulle tilstanden og dens epidemiologi. Dette var et problemområde med tilknytning til MFR som ingen hadde arbeidet med inntil da, og jeg tok opp med Peterson hvorvidt et forskningsmateriale basert på MFR ville være av interesse. Forespørselen innledet MFRs første formelle bilaterale forskningssamarbeid med en forskningsinstitusjon i USA. Samtidig etablerte UiB sitt samarbeidsprogram med University of Washington, der MFRs prosjekt om krybbedød ble et av de første konkrete tiltak.

På denne tiden var registerbasert epidemiologisk forskning knapt etablert som forskningsfelt. Analyser basert på registerdata ble sett på med skepsis; ikke uventet blant klinikere, men også blant mer konvensjonelt arbeidende epidemiologer, som baserte seg på egne større eller mindre ad hoc-prosjekter.

Krybbedød var tidlig på 1980-tallet en relativt sjelden tilstand med ca. 1 tilfelle per 1000 levendefødte $i$ Norge, men det var holdepunkter for at hyppigheten økte. $\AA$ få store forskningsmaterialer var ingen enkel oppgave og mange uløste spørsmål ventet. En viktig problemstilling var å fastslå om en mor som allerede hadde mistet ett barn, hadde økt risiko for krybbedød hos et nytt barn. Spørsmålet var også relevant med tanke på årsaksbakgrunnen for krybbedød.

To tidligere studier hadde vist at et nytt barn hadde en 10 ganger økt risiko, men resultatene ble trukket $i$ tvil fordi de var fremkommet i retrospektive studier. $\AA$ beregne en gjentakelsesrisiko for en sjelden tilstand nødvendiggjør meget store datamaterialer og dette var nå tilgjengelig i MFR. MFR ble koblet med Dødsårsaksregisteret og alle dødsmeldinger for barn døde $\mathrm{i}$ den aktuelle perioden ble gjennomgått. Dette førte til en betydelig reklassifisering av dødsfallene da det viste seg at særlig i de første årene etter 1967 ble mange krybbedødsfall feilaktig kodet som andre diagnoser, f.eks. øvre luftveisinfeksjon, forkjølelse o.l. Analyser av det reviderte datagrunnlaget viste at gjentakelsesrisikoen var betydelig lavere enn antatt, ca. 5 ganger økt risiko. Resultatet ble publisert uten større problemer og vakte internasjonal oppmerksomhet [17].

Men også her ble datagrunnlaget trukket i tvil og særlig av patologer som krevet at alle tilfellene skulle være obdusert hvis de skulle danne grunnlag for forsk- 
ning. I epidemiologisk forskning er dette en utopi og ville $i$ vårt tilfelle sannsynligvis ført til en overestimering av gjentakelsesrisikoen. At vi kunne vise at økningen av krybbedød i Norge utover i 1970- og 1980årene hadde sin parallell $\mathrm{i}$ en tilsvarende økning $\mathrm{i}$ den totale dødeligheten mellom 105. og 125. levedøgn, den alderen der krybbedødsraten var høyest og utgjorde henimot $60 \%$ av alle dødsfall [18], bidro til at kritikken mot MFRs diagnosegrunnlag etter hvert svant hen.

Denne forskningen ble utgangspunkt for en stor nordisk epidemiologisk krybbedødsstudie ledet av MFR, der vi påviste en relativ risiko på 15 for mageleie og en betydelig overrisiko, 4, også for sideleie [19]. Studien ble gjennomført i nært samarbeid med en gruppe i Göteborg ledet av Göran Wennergren. Den dannet også grunnlaget for en europeisk EU-finansiert studie initiert fra MFR og i samarbeid med London School of Hygiene and Tropical Medicine ved Robert Carpenter. Denne studien omfattet 20 land eller regioner og 745 tilfeller. Her ble samsoving etablert som risikofaktor og særlig hos røkende mødre [20].

Tidlig i 1990 gikk massemedia ut og advarte mot mageleie. Dette forte til et sterkt fall i hyppigheten av mageleie blant norske barn, fra 49,1\% i 1989 til 26,8\% i 1990. Samtidig avtok krybbedødsraten dramatisk fra 2,0 i 1989 til 1,1 per 1000 i 1990 [21] (figur 1). Denne undersøkelsen er et godt eksempel på at sammenhenger påvist $\mathrm{i}$ individbaserte studier (innen gruppekorrelasjon) bør samsvare med resultater av gruppebaserte økologiske studier (mellomgruppe-korrelasjon) for at sammenhengen skal kunne oppfattes som kausal. Den bidro også til at mageleie ble akseptert som en risikofaktor også i USA, der man lenge var skeptisk. På grunnlag av registerdata beregnet vi at over 1000 barn døde i Norge fordi mageleie ble anbefalt fra slutten av 1960-tallet. Antall sparte liv etter anbefalingen av ryggleie er også tankevekkende.

Samarbeidet med Peterson fortsatte til langt ut på 1990-tallet. Et enda mer omfattende vitenskapelig samarbeid ble på slutten av 1980-tallet etablert med Dr. Allen Wilcox ved National Institute of Environmental Health, North Carolina. Rolv Skjærven og Rolv Terje Lie har hatt tallrike opphold ved denne institusjonen, noe som har ledet til forskning med internasjonal gjennomslagskraft.

Peterson og Wilcox innså hvilket enormt forskningspotensiale MFR representerer. Mange andre har fulgt etter med ønske om å delta i forskning basert på data fra MFR. MFR har gitt Norge muligheter for internasjonal nisjeforskning i toppklassen, som knapt finnes $i$ andre land.

MFR har i lang tid deltatt $i$ internasjonale samarbeidsorganisasjoner og har således siden 1974 vært "founding member" i International Clearinghouse for Birth Defects Monitoring Systems. For å effektivisere arbeidet med overvåking og forskning ønsket Clearinghouse å opprette et International Centre for Birth Defects (ICBD). I skarp konkurranse med andre land og med betydelig støtte fra regjeringen lyktes det MFR å få lagt dette senteret til Norge. ICBD var virksomt i Bergen 1989-92.

MFR tok i 1997 initiativet til å opprette Nordic Association of Medical Birth Registries (NOMBIR) der alle de 5 nordiske land deltar. NOMBIR er en videreføring av et samarbeid fra 1971 (AFØD) under Nordisk medisinalstatistisk komité (NOMESCO) med formål å etablere nordisk fødselsstatistikk.

EU har siden 1979 gitt midler til EUROCAT som er et europeisk samarbeidsorgan for overvåking av medfødte misdannelser. Lenge måtte MFR stå utenfor dette samarbeidet på grunn av manglende norsk medlemskap i EU. EØS-avtalen endret dette og fra 1998 er MFR medlem av EUROCAT; fra 2007 fullt medlem fordi vi nå også leverer anonymiserte records til EUROCATs sentrale database. Den sentrale databasen muliggjør en langt mer effektiv og rask overvåking av medfødte misdannelser samtidig som den gir grunnlag for forskning.

Også innenlands har MFR etablert samarbeidsrelasjoner bl.a. med mange doktorgradsstipendiater ved andre institusjoner og forholdene er blitt lagt godt til rette for vekst. I 1996 var MFR initiativtaker til Locus for registerepidemiologi og ble autorisert som en prioritert forskningsgruppe av Det medisinske fakultet, UiB med betydelig pengestøtte. MFR deltar sammen med 7 andre enheter innenfor registermiljøet i Bergen. I årene 2001-2004 mottok MFR miljøstøtte fra Norges forskningsråd.

Stein Emil Vollset ble et bindeledd med et av fakultetets andre loci, Locus for homocysteinforskning, noe som har ført til viktige publikasjoner om risikofaktoren homocystein og ulike B-vitaminers betydning i svangerskapet og ved fødsel (se f.eks. [22]). Vollset var også en utmerket leder av MFR i min forskningstermin 2001-2002.

Driften av et stort helseregister forutsetter personellressurser. MFR har helt fra starten hatt engasjerte og ansvarsbevisste medarbeidere med et godt og stabilt arbeidsmiljø, noe som har bidradd til en profesjonell registerdrift. Noen av medarbeiderne har vært ansatt fra 1970-tallet og Anne-Grethe Sleire Graham helt fra begynnelsen.

Registerbasert epidemiologisk forskning krever også infrastruktur. Etter hvert ble forskningsvolumet så omfattende at det ble mulig å ansette en prosjektkoordinator og dette fikk stor betydning. Pat Schreuder ble ansatt i 1990 og fikk en sentral administrativ rolle i MFRs internasjonale krybbedødsforskning. Hun ble også prosjektkoordinator for ICDB og fra midten av 1990-årene fikk hun en tilsvarende rolle i planleggingen og oppbyggingen av Den norske mor og barn undersøkelsen (MoBa) ved MFR, et prosjekt som kom til å fylle tomrommet som oppsto da ICBD flyttet til Roma i 1992. MoBa er det største forskningsprosjektet som er etablert med utgangspunkt i MFR og er i dag en høyt prioritert virksomhet i FHI.

Samlet sett er forskningen ved MFR vokset til et betydelig omfang. Den første doktoravhandlingen som 
- KRYBBEDØD / SIDS PR. 1000

SOVING PÅ MAGE / PRONE SLEEPING PR. 100

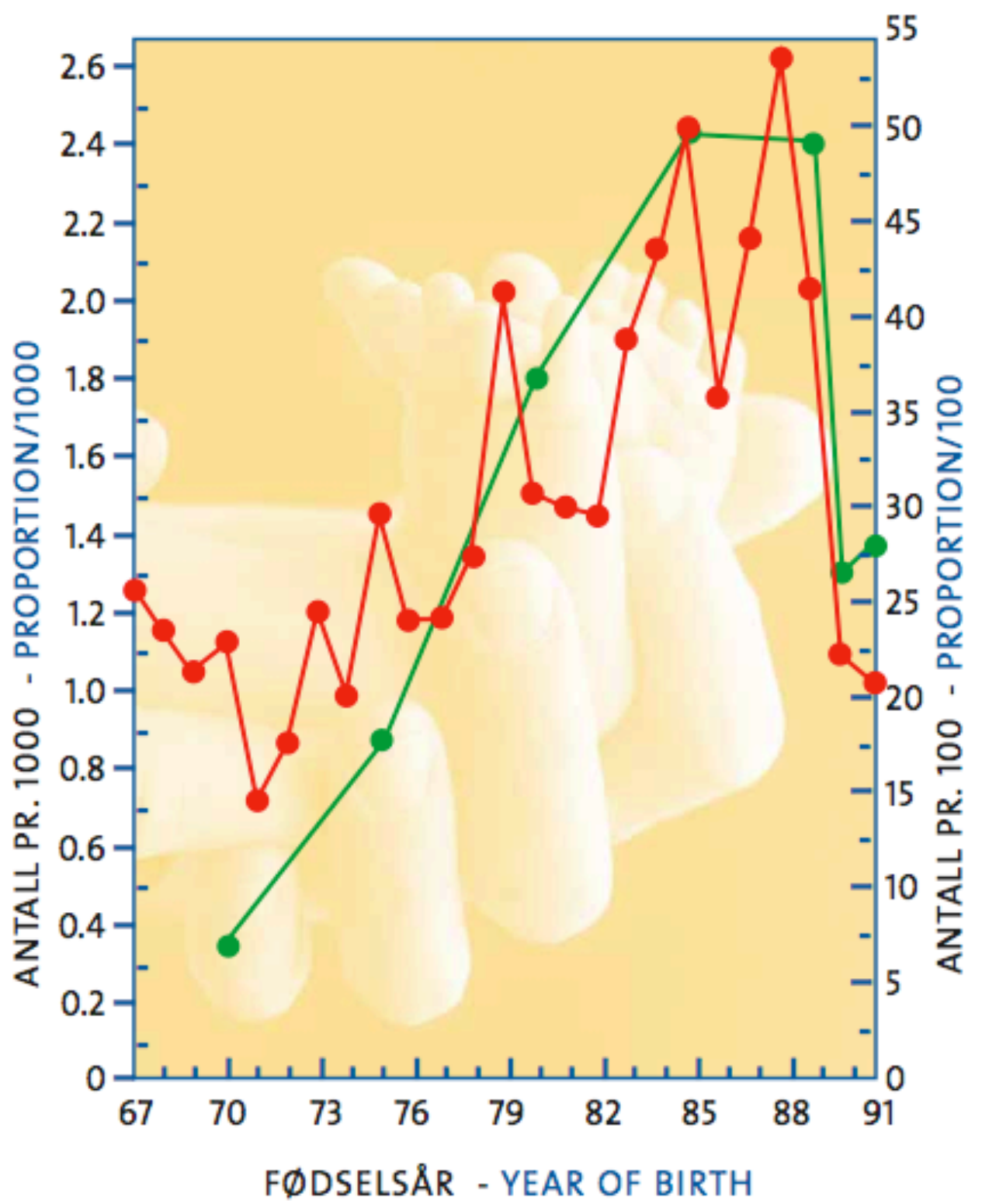

Figur 1. Forekomst (\%) av mageleie ved 3 måneders alder og forekomst av krybbedød (per 1000 som overlevde perinatalperioden) etter fødselsår.

utgikk fra miljøet var Rolv Skjærvens i 1989 [23]. Senere er den blitt fulgt av 25 avhandlinger basert på MFR-data og med veileder fra MFR. Blant doktorandene som senere har nedlagt en betydelig innsatsfor MFR kan nevnes Anne Kjersti Daltveit, Kari Klungsøyr, Rolv Terje Lie, Svein Rasmussen og Nina Øyen, som alle fremdeles er tilknyttet MFR samt Susanne Albrechtsen og Dag Moster som er post.doc.stipendiater. For tiden er 19 kandidater under veiledning, dels internt med tilknytning til UiB gjennom Institutt for samfunnsmedisinske fag, dels tilknyttet andre institusjoner. At også kvaliteten av forskningen er høy ble dokumentert i NFRs evaluering av samfunnsmedisinsk forskning i 2004 der den ble bedømt som "excellent" [24].

Også forskning basert på registerdata utført utenfor MFR har skutt fart, og MFR har, som nevnt, fått en egen oppdragsseksjon for utlevering av data. Fra tid til annen har forvaltere av viktige forskningsmaterialer blitt kritisert for manglende vilje til å levere ut data til andre institusjoner. Denne kritikken har nok i enkelte tilfeller vært berettiget. Derfor har jeg, så lenge jeg har hatt noen tilknytning til MFR, fremholdt overfor alle MFRs ansatte at vi skal ha en korrekt og tjenestevillig 
holdning overfor alle henvendelser om data slik at det ikke skal være grunnlag for denne typen kritikk overfor MFR. MFR har også hatt egne organer for å tilse praksis for utlevering av data. Fra 1995 til 2003 fungerte "Rådgivende utvalg for MFR" med fylkeslege Asbjørn Haugsbø som formann, og fra 2002 har MFR hatt et "Publikasjonsutvalg for MFR" med retningslinjer fastsatt av direktøren for Nasjonalt folkehelseinstitutt.

\section{KONTROVERSIELLE KJEPPHESTER OG VISJONER FOR FREMTIDEN}

På et møte i International Epidemiological Association i København i 1994 møtte jeg en meningsfelle, Dimitri Tricopoulos, som foreleste om epidemiologiens fremtid. Han mente at fremtiden ville bygges på to søyler:

- genetisk epidemiologi og

- megaepidemiologi.

Med megaepidemiologi mente Tricopoulos registerbasert epidemiologi. Han hørte til dem som var blitt fascinert av Nordens epidemiologiske skatter i form av registre og benyttet møtet i København til å komme med denne bekjennelsen.

Senere har epidemiologien vært gjennom en selvransakelse der observasjonsstudier, av enkelte deltakere i debatten, nærmest ble brakt inn i en eksistensiell krise. Eksempler ble hentet frem på hvordan feiltolkninger har fătt uheldige konsekvenser. Men en generell avskrivning av observasjonsstudier er neppe holdbar. Bare den krybbedødsforskningen MFR har deltatt $\mathrm{i}$ viser epidemiologiens potensial i fremtidig forskning knyttet til sykdomsårsak og forebyggelse. På den annen side er kritisk debatt og bevissthet om arbeidsmåtenes begrensninger viktig og nødvendig. Kritisk holdning og bevisst bruk har således ført den lenge avskrevne pasient-kontrollstudien til heder og verdighet igjen blant annet i form av såkalt "nested pasient-kontrolldesign".

MFR bygger i realiteten sin forskningsstrategi på Tricopoulos' to søyler. Med over 2,5 millioner fødsler kvalifiserer vi meget vel for begrepet megaepidemiologi. Den genetiske epidemiologiske forskningen er kommet til uttrykk, dels i studier av søskenflokker og foreldre-barnrelasjoner der bl.a. Rolv Skjærven har vært særlig aktiv, dels i studier av fenotyper og genotyper i mor-far-barnstudier der Rolv Terje Lie har bidradd tungt både metodologisk og med resultater knyttet i første rekke til leppe-ganespalte. I dette SAM-prosjektet var Nina Hovland en utmerket prosjektkoordinator.

Tidlig på 1990-tallet lanserte David JP Barker sin teori om intrauterin programmering som årsak til sykdom hos voksne. I Norge var Anders Forsdahl tidlig inne på lignende tanker. Teorien innebærer eksempelvis at dårlig ernæring $\mathrm{i}$ fosterlivet gir økt risiko for hjertekarsykdom i voksen alder. En sammenheng mellom lav fødselsvekt og høy hjertekardødelighet blir tolket på denne måten. Uansett hva man måtte mene om denne tolkningen førte Barkers teori til en sterkt økende interesse for perinatale forskningsdata. Disse dataene danner grunnlag for det som nå kalles livsløpsepidemiologisk forskning [25], en forskning der ennå mye er ugjort. Også på dette feltet er MFRforskningen vel etablert og bygger i stor utstrekning på koblete datagrunnlag, f.eks. med data fra Kreftregisteret eller Dødsårsaksregisteret. Slike registerkoblinger vil bli stadig viktigere. På denne bakgrunn rir jeg stadig kjepphesten om at enhver norsk epidemiologisk studie også bør omfatte variabler fra MFR, enten i form av utfall, eksposisjon eller effektforvekslingsvariabler (confoundere).

$\AA$ etablere et effektivt, enkelt og praktisk, men samtidig trygt regelverk rundt slike koblinger er viktig. For MFR vil oppfølgingsdata fremover mot voksen alder være nødvendige for å belyse risiko knyttet til forhold i svangerskapet, ved fødselen og i nyfødtperioden, med andre ord for å identifisere perinatale risikofaktorer av betydning for helse i voksen alder. Slike oppfølgingsdata kan ikke bare skaffes ved kobling med etablerte helseregistre. Det må også legges til rette for nye rutiner der andre helsedata benyttes. Allerede i dag blir MFR rutinemessig oppdatert med opplysninger om tilstander som var til stede ved fødselen eksempelvis gjennom Norsk nyfødtmedisinsk kvalitetsregister (barn overført til barneavdeling etter fødselen) og gjennom cerebral parese registeret. I fremtiden vil det være ønskelig å utvide datagrunnlaget til å omfatte opplysninger fra helsestasjon og skolehelsetjeneste og eventuelt Norsk pasientregister, men dette vil gjøre det nødvendig med forskriftsendringer.

$\AA$ etterprøve Barkers (og andres) hypoteser vil bli viktige fremtidige utfordringer. Men en hypotese oppstår ofte tilfeldig ved at en enkeltperson av en eller annen grunn får en idé om en årsakssammenheng. $\AA$ benytte et forskningsmateriale til å oppdage andre sammenhenger enn den hypotesen man opprinnelig var opptatt av å teste, blir ofte raljerende omtalt som en fiskeekspedisjon og uten videre avvist. Jeg vil imidlertid hevde at en slik holding kan virke lammende og fremskrittsfiendtlig. Som en forvalter av store datamengder føler jeg i stadig større grad ubehag ved en passiv forskningsstrategi der kun etablerte hypoteser skal testes. Vi må i fremtiden få aksept for metoder som innebærer systematisk søk etter sammenhenger $i$ store datamengder uavhengig av en utgangshypotese. Et retorisk grep for å fremme slik hypotesegenererende forskning vil kunne være å erstatte uttrykket "fishing expedition" med "data mining".

Hvordan skal våre helseregistre administreres i fremtiden? Hvem skal drive registrene? Det hevdes stadig at registerdrift er en oppgave som kan og bør overlates til tekniske driftsmiljøer utenfor selve helsevesenet, som for eksempel Statistisk sentralbyrå (SSB). En slik oppfatning vil jeg advare mot. Erfaringer fra et par års arbeid med Medisinsk melding av fødsel var nok til å overbevise kloke aktører på slutten 
av 1960-tallet om at MFR ville bli faglig sett bedre forvaltet utenfor SSB. MFRs erfaring med koding av dødsårsaker i første leveår i Dødsårsaksregisteret ga grunnlag for en tilsvarende konklusjon; registeransvaret for Dødsårsaksregisteret er nå overført til FHI. Forsvarlig drift av et helseregister forutsetter en kompetent medisinsk ledelse. Medisinsk kompetanse er nødvendig for kode- og klassifiseringsarbeid, for sikring av datakvalitet, for viktige faglige prioriteringer og for en effektiv datautleveringstjeneste $i$ forbindelse med eksterne oppdrag. De sentrale helseregistrene har sin organisatoriske plass i FHI. Men det er viktig at høykompetente driftsmiljøer bevares og videreutvikles. At et slikt driftsmiljø er sterkt også vitenskapelig er den beste garanti for høy datakvalitet og dermed av stor betydning både for forskning og forvaltning. Et slikt driftsmiljø er også nødvendig for at ønsker om økt aktualitet og mer effektiv helseovervåking skal bringes fra visjon til realitet.

\section{AvsLutning}

Historien som er fortalt her er tilsynelatende preget av tilfeldighetenes spill, men likevel tilfeldigheter som i noen grad ble utnyttet av tilstedeværende aktører. Dermed er sirkler sluttet og utviklingstrekk trer frem slik at man kan få mistanke om en større plan bak det hele. Var det hele et ledd i en uunngåelig historisk utvikling? Systematisk å dra medisinsk lærdom av et stort antall enkeltskjebner med formål å forebygge sykdom til fellesskapets beste; slik kan registerbasert epidemiologisk forskning beskrives. En slik utvikling måtte komme. De første tegn til denne tenkemåten kom på 1800-tallet da legene i større grad begynte å resonnere på grunnlag av grupper av individer og ikke bare enkeltpasienter. Etableringen av Lepraregisteret må sees i et slikt perspektiv. Likevel var nok Lepra- registeret på flere måter forut for sin tid, noe en mer enn 100 års Tornerosesøvn kan vitne om.

Utviklingen av MFR ble imidlertid ikke preget av søvn. Selv om lykkelige tilfeldigheter nok har spilt en viss rolle også her, er historien om MFR først og fremst preget av medarbeideres entusiastiske innsats og støttespilleres klarsynte visjoner. Jeg fremhever ofte at høy faglig registerkompetanse er MFRs grunnfjell. Dette utgjøres av ansvarsbevisste medarbeidere med til dels lang fartstid ved MFR og disse bidrar til et godt arbeidsmiljø. Følgende har fått Norges Vels medalje for lang og tro tjeneste: Anne-Grethe Sleire Graham, Rannveig Aardal, Torill Holmar og Aase Karin Larsen.

De store linjene i historien som her er trukket opp, bærer ikke tilfeldighetenes preg. Helsevesenets behov for registerdata kom like klart til uttrykk i 1856 som i 1967, og er ikke blitt mindre etter dette. Forskjellen er at i dag har vi en teknologi som gjør det mulig å utnytte våre registerdata langt mer effektivt til bedre helse for alle. Dette er ikke bare en fremtidsvisjon, men en realitet allerede $\mathrm{i}$ dag. Håpet er at vi makter å synliggjøre både realiteten og visjonen, å overbevise alle om at veien er riktig og viktig, og at vi lykkes med å skaffe de ressurser som er nødvendige for å nå de målene vi har satt.

\section{TAKK}

Det er mange som har deltatt i den historien som her er fortalt, og som har ytet verdifulle bidrag. I vedlegget finnes en oversikt over alle ansatte og stipendiater ved MFR per august 2007. Jeg vil rette en spesiell takk til min sekretær gjennom mange år, Truls P. Næss, som alltid har vært til uvurderlig hjelp og ikke minst med denne artikkelen. Til slutt til alle nevnte og unevnte: en stor takk for innsatsen til hver især.

\section{REFERANSER}

1. Irgens LM. Leprosy in Norway: An interplay of research and public health work. Int J Leprosy 1973; 41: 189198.

2. Irgens LM, Bjerkedal T. Epidemiology of leprosy in Norway: the History of The National Leprosy Registry of Norway from 1856 until today. Int J Epidemiol 1973; 2: 81-89.

3. Irgens LM. The discovery of Mycobacterium Leprae. A medical achievement in the light of evolving scientific methods. Am J Dermatopathol 1984; 6: 337-343 (Commissioned by the journal).

4. Irgens LM. Leprosy in Norway. An epidemiological study based on a national patient registry (Doctoral thesis). Lepr Rev 1980; 51 (Suppl 1): 1-130.

5. Irgens LM, Skjærven R. Secular trends in age at onset, sex ratio and type index in leprosy observed during declining incidence rates. Am J Epidemiol 1985; 122: 695-705.

6. Kazda J, Irgens LM, Müller K. Isolation of non-cultivable acid-fast bacilli in sphagnum and moss vegetation by foot pad technique in mice. Int J Lepr 1980; 48: 1-6.

7. Irgens LM, Melo Caeiro F, Lechat MF. Leprosy in Portugal 1946-1980. Epidemiologic patterns observed during declining incidence rates. Lepr Rev 1990; 61: 32-49.

8. Meima A, Irgens LM, Oortmarsen GJv, Richardus JH, Habbema JD. Disappearance of leprosy from Norway: exploration of critical factors using an epidemiological modelling approach. Int $J$ Epidemiol 2002; 31: 9911000. 
9. Bjerkedal T, Bahna SL. The course and outcome of pregnancy in women with epilepsy. Acta Obstet Gynecol Scand 1973; 52: 245-248.

10. Bjerkedal T, Bahna SL, Lehman EH. The course and outcome of pregnancy in women with pulmonary tuberculosis. Scand J Resp Dis 1975; 56: 245-250.

11. Bahna SL, Bjerkedal T. The course and outcome of pregnancy in women with bronchial asthma. Acta Allergol 1972; 27: 397-406.

12. Bakketeig LS. The risk of preterm or low birthweight delivery. I: Reed DM, Stanley FJ, red. The Epidemiology of Prematurity. Baltimore: Urban \& Schwazenberg, 1977: 231-41.

13. Bjerkedal T, Bakketeig LS. Surveillance of congenital malformations and other conditions of the newborns. Int J Epidemiol 1975; 4: 31-36.

14. Irgens LM. Fødselsregisteret, historie og fremtidige oppgaver. I: Tellnes G, Larsen Ø, red. Epidemiologi og forebyggende helsearbeid. Festskrift ved Tor Bjerkedals 70 årsdag. Oslo: Universitetet i Oslo, 1996: 12-19.

15. Irgens LM, red. Fødsler i Norge 1999-2000. Årsmelding, Medisinsk fødselsregister. Folkehelseinstituttet/UiB, 2002: 10-12.

16. Irgens LM, Hellesøy OH. The school health services and psycho-social health problems. Operational diagnostics and intervention. Scand J Soc Med 1980; Suppl 24: 27-34.

17. Irgens LM, Skjærven R, Peterson DR. Prospective assessment of recurrence risk in sudden infant death syndrome siblings. I: Oski F, Stockman JA, red. The Yearbook of Pediatrics. Chicago: Yearbook Medical Publishers, 1985: 570-571.

18. Irgens LM, Skjærven R, Lie RT. Secular trends of sudden infant death syndrome and other causes of post perinatal mortality in Norwegian birth cohorts. Acta Paediatr Scand 1989; 78: 228-232.

19. Øyen N, Markestad T, Skjærven R, Irgens LM, Helweg-Larsen K, Alm B, Norvenius G, Wennergren G. Combined effects of sleeping position and prenatal risk factors in sudden infant death syndrome (SIDS). The Nordic Epidemiological SIDS Study. Pediatrics 1997; 100: 613-621.

20. Carpenter RG, Irgens LM, Blair P, England PD, Fleming P, Huber J, Jorch G, Schreuder P. Sudden unexplained infant death in 20 regions in Europe: case control study. Lancet 2004; 363: 185-191.

21. Irgens LM, Markestad T, Baste V, Schreuder P, Skjærven, Øyen N. Sleeping position and sudden infant death syndrome in Norway 1967-91. Arch Dis Child 1995; 72: 478-482.

22. Vollset SE, Refsum H, Irgens LM, Emblem BM, Tverdal Aa, Hansen ALB, Ueland PM. Plasma total homocysteine, pregnancy complications and adverse outcomes: The Hordaland Homocysteine Study. Am J Clin Nutr 2000; 71: 962-968.

23. Skjærven R. Dependencies in perinatal outcome between successive siblings. Influences on traditional measures in perinatal epidemiology assessed on the basis of births in Norway, 1967-1984 (Doctoral thesis). Section of Medical Informatics and Statistics, University of Bergen, 1989.

24. Evaluation of clinical, epidemiological, public health, health-related and psychological research in Norway. Public health and health services research, Panel 2. Oslo: The Research Council of Norway 2004: 38-39. ISBN: 82-12-01904-7.

25. Irgens LM, Kristensen P, Vatten LJ, red. Tema: Tidlig eksponering og senere sykdom. Norsk Epidemiologi 2005; 15 (1): 1-118. 


\section{OVERSIKT OVER ANSATTE VED MFR PER AUGUST 2007}

\section{Administrasjon}

Leder: Lorentz M. Irgens, avdelingsdirektør, professor dr.med.

Stab:

Nina Reigstad, 1.konsulent, personalforvaltning

Anne-Lise Singstad, 1.konsulent, økonomiforvalting

Truls P. Næss, konsulent, bibliotek, registerfunksjoner og andre oppgaver

Hilde Mæland, informasjonskonsulent

\section{SEKSJON FOR DATAMOTTAK}

Leder: Kari Klungsøyr, førsteananuensis dr.med., overlege

Medarbeidere:

Anne-Grethe Sleire Graham, 1.konsulent

Rannveig Aardal, 1.konsulent

Aase K. Larsen, konsulent

Berit P. Lien, 1.konsulent

Torill Holmar, 1.konsulent

Ingrid Haavik Nystad, konsulent

Henriette Hagen Hansen, konsulent

Svein Rasmussen, professor dr.med., medisinsk konsulent (bistilling)

\section{SEKSJON FOR IT-OPPGAVER OG REGISTERSERVICE}

Leder: Erik Lie-Nielsen, cand.scient., overingeniør

\section{Medarbeidere:}

Øyvind Leegaard, avdelingsingeniør

Inge Geithus, cand.mag., overingeniør

Olav Kjetil Hugaas, cand.mag., overingeniør

Arild Sunde, overingeniør (MoBa)

Elin Alsaker, siv.ing., rådgiver $(\mathrm{MoBa})$

Yngve Klakegg, overingeniør

Ole-Henrik Edland, rådgiver

Bjørn Espen Espedal, cand.mag., avdelingsingeniør (MoBa)

Mads Hjelle, siv.øk., rådgiver (MoBa)

Ole-Martin Kvinge, cand.mag., overingeniør (MoBa)

\section{SEKSJON FOR EKSTERNE OPPDRAG/FILPRODUKSJON}

\section{Medarbeidere:}

Steinar Nilssen, cand.mag., rådgiver

Jon Gunnar Tufta, cand.mag., rådgiver

Magnhild Viste, rådgiver

\section{DEN NORSKE MOR OG BARN UNDERSØKELSEN (MOBA)}

Enhetsleder: Patricia Schreuder, cand.mag., rådgiver

Medarbeidere:

Marianne Bjørnen, konsulent

Maria Theresa Gonzales Acuero, konsulent

Maria Omland, konsulent

Linda Kristoffersen, konsulent

Eldbjørg Bjelland, sykepleier, konsulent

Ingunn Riise, konsulent

Christine M. Bergflødt, konsulent

Erna Davidsen, konsulent

Linda Dvergsdal, konsulent

Grethe Karin Eriksen, konsulent 


\section{ABORT OG IVF-REGISTRERING}

Leder: Kristin Gåsemyr, cand.polit., prosjektleder

\section{Medarbeidere:}

Aase Gunn Mjaatvedt, 1.konsulent

Eirin Mo, 1. konsulent

Brankica Kajmakovic, konsulent

Inger Elise Engelund, cand.polit., førstekonsulent

Ingvei Seliussen, siv.ing., overingeniør

Kristina Totlandsdal, seniorrådgiver (bistilling)

\section{BIOBANKREGISTERET}

Nina Hovland, prosjektkoordinator/ rådgiver

Nguyen Trung Truc, rådgiver

Nina Øyen, førsteamanuensis, dr. med. MPH, seniorrådgiver (bistilling)

\section{BISTILLINGER}

Dag Moster, post.doc., dr.med.

Astanand Jugessur, post.doc., dr.philos.

Tone Bjørge, professor dr.med.

Anne-Kjersti Daltveit, forsteamanuensis, dr.philos.

Rolv Terje Lie, professor dr.philos.

Rolv Skjærven, professor dr.philos.

Stein-Emil Vollset, professor Dr.PH.

STIPENDIATER (SEKSJON FOR EPIDEMIOLOGI OG MEDISINSK STATISTIKK, UiB)

Ndema Habib, cand.med.

Roy M. Nilsen, cand.scient.

Tone Nordtvedt, cand.med.

Åse Sivertsen, cand.med.

Mette C. Tollånes, cand.med. 